\title{
Current State and Factors of Kazakhstan Compulsory Retail Insurance Potential Formation
}

\author{
Azamat Rashidovich Kerimbayev ${ }^{1}$ \\ ${ }^{1}$ Al-Farabi Kazakh National University, Almaty, Kazakhstan \\ Correspondence: Azamat Rashidovich Kerimbayev, Masanchi 98A, Almaty 050022, Kazakhstan. Tel: \\ 7-701-980-2020. E-mail: azamat.kerimbayev@yandex.kz
}

\author{
Received: March 19, 2015 Accepted: April 21, 2015 Online Published: May 14, 2015 \\ doi:10.5539/res.v7n7p317 URL: http://dx.doi.org/10.5539/res.v7n7p317
}

\begin{abstract}
The article focuses on the high priority of the insurance market development as an integral element of the market infrastructure of the Kazakhstan economy within the framework of determining the economic value of compulsory retail insurance. The economic content, tasks, and basic principles of the market of compulsory retail insurance in Kazakhstan were outlined. The position of compulsory retail insurance in the insurance market of the state was identified. The main type of compulsory retail insurance in the Republic of Kazakhstan, that is insurance of civil and legal liability of vehicle owners, was described and analysed. Basic tendencies of the market of compulsory retail insurance in Kazakhstan were identified. These include stable development with reduced economic efficiency due to the tendencies of companies to reduce insurance premiums when insuring civil and legal liability of vehicle owners. Specific features of the development of the compulsory retail insurance market of the Republic of Kazakhstan were determined. These are revealed in the regional and functional market concentration leading to its reduced competitive power and quality of insurance services. Using a principle component analysis (factor analysis), the level of impact of the social and economic state of the Republic of Kazakhstan and development trends of the world economy's financial and economic sectors on the development of the Kazakhstan market of compulsory retail insurance was identified. A complex of measures was outlined to enhance the efficiency of the compulsory retail insurance market in Kazakhstan. In addition, it creates sources for building its financial potential in order to maintain the forecasted positive tendency of increasing the market efficiency for 2015 based on the major factor loadings of social and economic state of the Republic of Kazakhstan as well as development trends of the world economy's financial and economic sectors.
\end{abstract}

Keywords: insurance, market of compulsory retail insurance of the Republic of Kazakhstan, insurance of civil and legal liability of vehicle owners, insurance premiums, insurance benefits, economic effect

\section{Introduction}

\subsection{Introduce the Problem}

Ensuring the security of a society is an indispensable condition for a state's normal development in market conditions. In a market economy, the state is no longer liable for damages caused to business entities and citizens by undesired events, natural disasters, and catastrophes. The tool capable of compensating for the incurred damages and losses in market conditions is insurance. The results of insurance services are an important factor stimulating the economic activity of separate regions and provide a positive impact on the economy of the entire republic. The transition to a market economy, entrepreneurship development, expansion of trading and exchange operations, mutual contractual obligations between business entities reasonably require a reliable safeguards system provided by insurance.

\subsection{Importance of the Problem}

Currently the Republic of Kazakhstan is listed among the countries with the highest car-crash fatality rates. This is why over the past few years retail insurance, along with manufacture and trade, has taken one of the key positions in the system of social reproduction of Kazakhstan. Its importance can be compared with that of the security of the whole society and is legally regulated by the state. This ensures the relevancy and timeliness of the scientific priority in researches of the modern state, tendencies, and prospects of the development of the compulsory retail insurance market in Kazakhstan. 


\subsection{Relevant Scholarship}

The analysis of research results of leading scientists and relevant literature indicates a thorough theoretical knowledge of problems of the market of compulsory retail insurance and identifying its development trends. Researchers whose work deserves special attention include Zhilkina (2014), Kindurys (2011), Sira (2014), Lawson (2013), Tuten (Tuten, 2013), Zhuyrikov (2013), Hasenova (2010), Saimbetova and Isakova (2011), Saimbetova and Isakova (2011), Hasenova (2010), and others. Meanwhile, giving credit to the existing scientific groundwork of scientists-economists, there is still a need to design conceptual suggestions to develop measures to increase the efficiency of the compulsory retail insurance market by determining impact factors of the national and world economy's development trends affecting it as well as identifying forecasted market rates based on the basic factor loadings.

\subsection{State Hypotheses and Their Correspondence to Research Design}

The framework of studying the compulsory retail insurance system involves debatable and ambiguous nature of the conceptual approaches. Thus, the main research objective is identifying and presenting arguments about the peculiarities of the market of compulsory retail insurance illustrated by the Republic of Kazakhstan, forecasting its development trends based on the determined external and internal environment impact factors.

The research is dedicated to resolving a number of conceptual questions:

1) Proving the high priority of compulsory retail insurance development as a factor of social security in the Republic of Kazakhstan;

2) Analysing and determining peculiarities of the functioning of the market of retail insurance in Kazakhstan;

3) Identifying main exogenous and endogenous factor groups determining the state and development prospects of the market of compulsory retail insurance in the Republic of Kazakhstan;

4) Forecasting efficiency trends of the Kazakhstan market of compulsory retail insurance based on the basic impact factors of the national and world economy's conditions.

\section{Method}

To achieve the research objective and solve the research tasks set, general and special scientific methods were applied:

\subsection{Statistical Observation}

In the research, using a random statistical observation, a database was formed to determine the current state of the market of compulsory retail insurance of the Republic of Kazakhstan. Based on the scientifically organized data collection on the amount of insurance benefits and premiums, a database was formed to analyse the state and identify tendencies of the insurance market. Collecting data on the amount of insurance transactions allowed a database to be formed to enable a quantitative perception of the efficiency and concentration of the market of compulsory retail insurance in Kazakhstan. With the use of a random statistical observation, an empirical data collection on the social and economic state of Kazakhstan as well as development trends of the world economy's real and financial sectors was formed to identify their impact on the development of the market of compulsory retail insurance in Kazakhstan.

\subsection{Analysis and Measurement}

Based on the database formed on the state of the market of compulsory retail insurance in the Republic of Kazakhstan, a statistical abstract was formed by means of analysis on the amount of insurance benefits, insurance premiums, and insurance transactions for various regions of Kazakhstan and for various companies. The statistical abstract of quantitative data made it possible, by measuring the insurance market relative indicators, to determine the efficiency of compulsory retail insurance in Kazakhstan in 2009 to 2014.

\subsection{Principle Component Analysis}

The system of empirical data formed on the social and economic state of the Republic of Kazakhstan and development trends of the world economy's financial and economic sectors consisting of 43 indicators to determine hidden (latent) causes explaining the correlation between the characteristics and multiparametric object visualizations became available. Thus, it is now possible to evaluate qualitatively the loading levels factor of the social and economic state of Kazakhstan and development trends of the world economy's financial and economic sectors on the development of the market of compulsory retail insurance in Kazakhstan, and quantitatively describe their impact levels. 


\subsection{Correlation-Regression Analysis}

The classical method of stochastic simulation provided a quantitative evaluation was to the correlation between the efficiency indicators of the Kazakhstan compulsory retail insurance market and main impact factors of the social and economic state of Kazakhstan. In addition, it evaluated the development trends of the world economy's financial and economic sectors. The evaluation included the fact that the relationship between them is not strictly functional and is distorted by random external factors. Due to the trend line, potential quantitative indicators of factor loadings were identified, making it possible to build a multifactor model to forecast the efficiency of the market of compulsory retail insurance in Kazakhstan.

\subsection{Empirical Generalization and Logical Inference}

A cognitive process was applied to single out relatively consistent features of the functioning of the compulsory retail insurance market. Its basic principles were identified; the same was done to the main type of compulsory retail insurance in Kazakhstan that is insurance of civil and legal liability of vehicle owners. It made it possible to establish the empirical fact of the high priority of the development of the market of compulsory retail insurance in the Republic of Kazakhstan.

By identifying consistent peculiarities of the development of the market of compulsory retail insurance, such as its tendency, economic efficiency, and concentration, it became possible to determine factors influencing the development of the Kazakhstan insurance market, and, by means of logical inference, making conceptual recommendations as to how to enhance its efficiency within the state.

\section{Results}

The Kazakhstan economy is the largest economy in Central Asia. The country has extensive deposits of oil, as well as minerals and metals. With its steppes enabling to grow both cattle and grain, Kazakhstan has a significant agriculture potential, while due to its well-developed space infrastructure spaceships are launched from Kazakhstan to the International Space Station. The establishment of a socially oriented market economy in Kazakhstan required fundamental changes in the principles of economic management, attraction of new and modernization of the traditional tools of economic management (Ing \& Elena Sira, 2014). Under present-day conditions, as best practices show, the most effective is the system of insurance, an essential category of the system of market economic relations designed to protect property interests of citizens and business entities of the economy using market methods (Kindurys, 2011).

Nowadays, the Kazakhstan insurance market remains small. According to Swiss Re's 2013 sigma study, the country comes 42nd in the world, leaving behind Morocco and following Serbia (Global insurance review 2014 and outlook 2015/16, 2015). In 2013, Kazakhstan's total insurance premiums accounted for $0.04 \%$ of the world's total insurance premiums (International Insurance Fact Book, 2015).

One of the main sources of insurance system potential formation in Kazakhstan is the market of compulsory retail insurance which economic value is determined by the following factors:

- Ensures financial stability;

- Contributes to a more efficient distribution of national capital;

- Ensures effective risk management;

- Contributes to the development of trade, including international one;

- Mobilizes national savings (Milyaeva \& Ninua, 2014).

The primary type of compulsory retail insurance in Kazakhstan is insurance of civil and legal liability of vehicle owners (On Insurance Activity (Law of the Republic of Kazakhstan No.126-II, 2000), (On Approved Compulsory Insurance Types (Order of the Prime Minister of the Republic of Kazakhstan No.38-p), 2003).

Compulsory insurance of civil and legal liability of vehicle owners is a type of insurance providing insurance benefits for full or partial compensation of damages, caused to the life, health and (or) property of third parties resulting from the use of a vehicle as a source of increased danger. (On Compulsory Insurance of Civil and Legal Liability of Vehicle Owners as of July 1, 2003, No.446-II).

The aim of compulsory insurance of liability of vehicle owners in the Republic of Kazakhstan is to ensure the protection of property interests of third parties, to which life, health and (or) property damage was caused resulting from the use of vehicles by means of paying out insurance benefits.

This type of retail insurance is based on the following system of principles (Figure 1). 


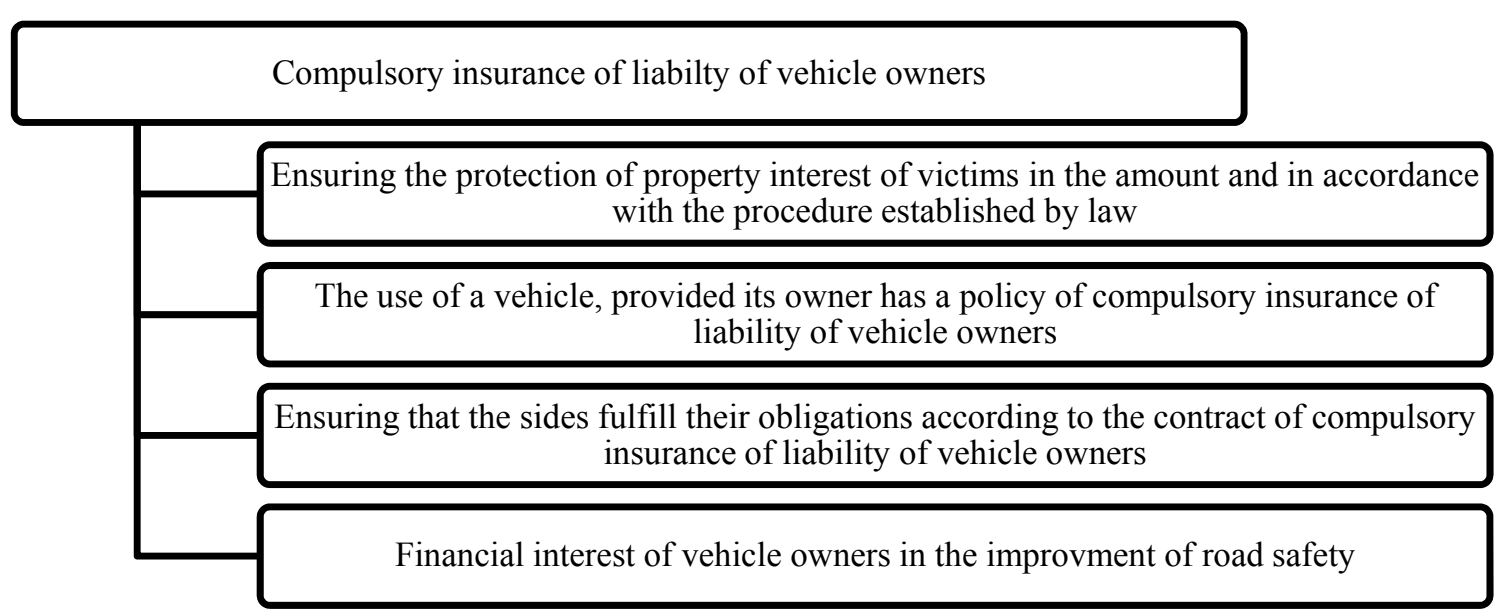

Figure 1. Basic principles of compulsory retail insurance in Kazakhstan

Note. Made by the author based on the information from Zhuyrikov (2014), on Compulsory Social Insurance (Law of the Republic of Kazakhstan No. 405-II, 2003).

The analysis indicates that compulsory retail insurance in Kazakhstan has a major share in the insurance market. Thus, the share of the compulsory retail insurance benefits in the structural relation between the types of insurance in Kazakhstan, as the analysis shows, has had a positive tendency during the period under review. As compared with 2009 , in 2014 a $20 \%$ increase can be seen in the share of voluntary personal insurance, $71.2 \%$ in voluntary property insurance, and $12.3 \%$ (Figure 2 ) in compulsory insurance.

- Compulsory insurance $\varpi$ Voluntary property insurance $\varpi$ Voluntary personal insurance

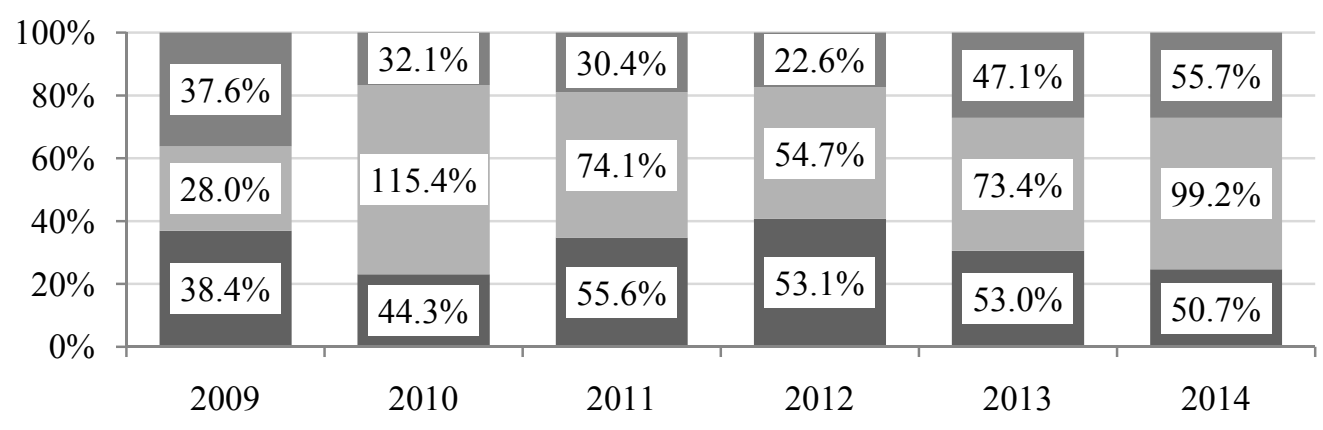

Figure 2. Tendency in the share of compulsory retail insurance benefits in Kazakhstan's insurance sectors

Note. Made by the author based on the information from Official website of the National Bank of the Republic of Kazakhstan (2015).

This stresses the leading positions and significance of compulsory retail insurance in the insurance market and financial security of Kazakhstan.

A rising tendency in compulsory retail insurance benefits is also seen relative to the entire insurance market of Kazakhstan. Thus, the share of the insurance benefits paid out with regard to insurance of civil and legal liability of vehicle owners in 2014 accounted for almost $21 \%$ of total insurance benefits, which is a $10 \%$ increase as compared with 2009 (Figure 3). 
Civil and legal liability of vehicle owners $\quad-$ Share in total insurance benefits, \%

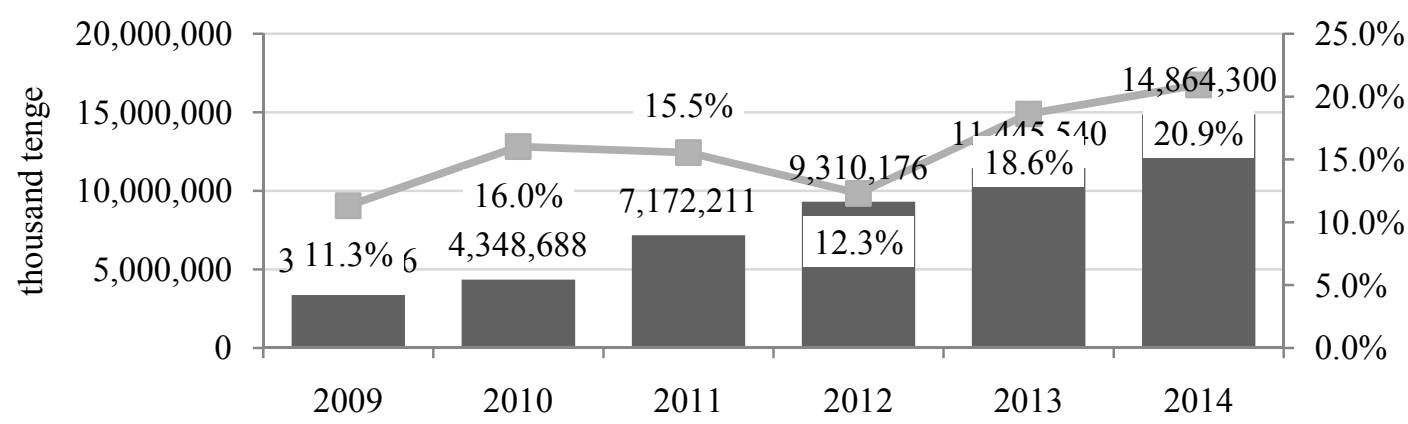

Figure 3. Tendency in compulsory retail insurance benefits in Kazakhstan

Note. Made by the author based on the information from Official website of the National Bank of the Republic of Kazakhstan (2015).

Regarding the financial potential of the market of compulsory retail insurance, it should be noted that there was an obvious negative tendency in receiving insurance premiums during the reviewed period in the structural relation between the insurance types. Thus, as compared with 2009, in 2014 a $32.5 \%$ decrease can been seen in the share of compulsory retail insurance in voluntary personal insurance, and a $7.2 \%$ decrease is seen in voluntary property insurance. Despite an insignificant increase of $4.5 \%$ (Figure 4) in the share of compulsory insurance premiums and an $85 \%$ growth in their absolute value, there was a $4.1 \%$ decrease in the share of compulsory retail insurance premiums in the insurance market of Kazakhstan (Figure 5).

- Compulsory insurance $\square$ Voluntary property insurance $\square$ Voluntary personal insurance

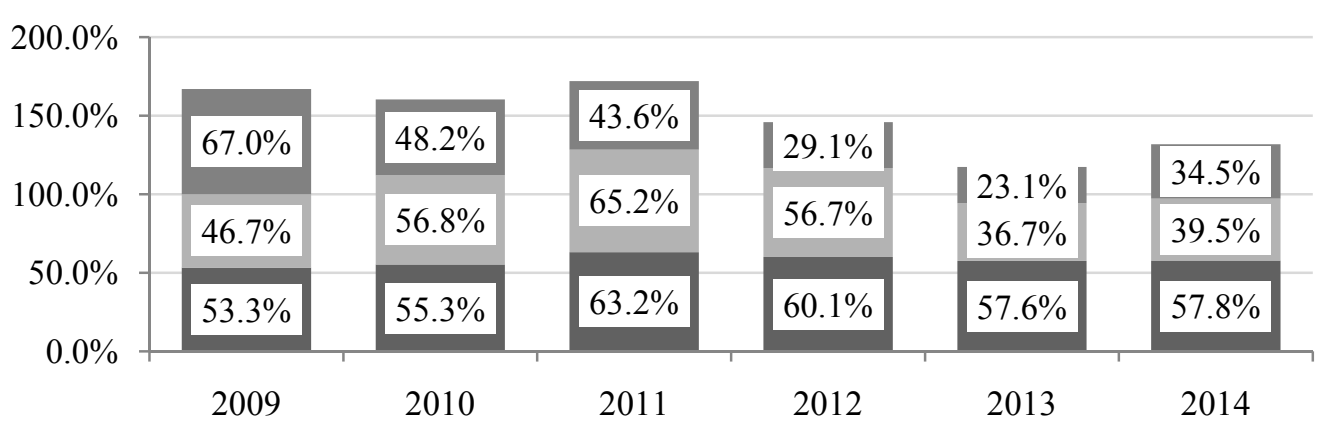

Figure 4. Tendency in the share of net insurance premiums of compulsory retail insurance in Kazakhstan's insurance sectors

Note. Made by the author based on the information from Official website of the National Bank of the Republic of Kazakhstan (2015). 


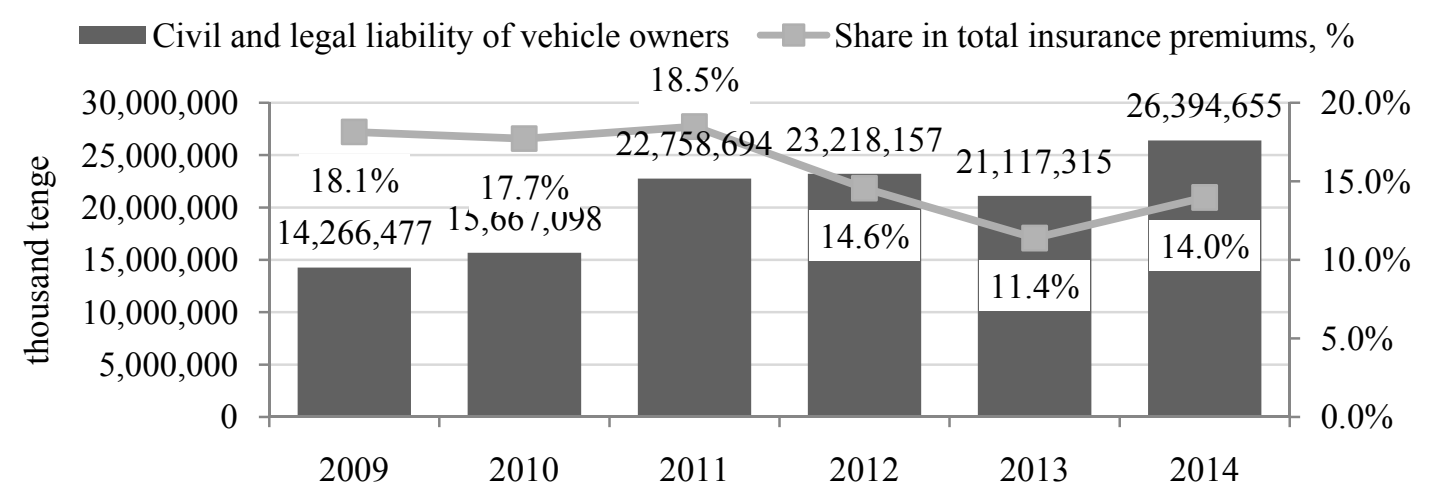

Figure 5. Tendency in earned net insurance premiums of compulsory retail insurance in Kazakhstan

Note. Made by the author based on the information from Official website of the National Bank of the Republic of Kazakhstan (2015).

This was due to increased insurance benefits paid out by compulsory insurance companies resulted from an increase in traffic accidents in Kazakhstan. Thus, over 3 thousand people were killed and about 17 thousand were severely injured in motor vehicle crashes on the roads of Kazakhstan yearly. (Kazakhstan is listed among the counties with the highest traffic-related death rates, 2014). Over the past 6 years, there was an $86 \%$ increase in the number of road accidents $(+9,364$ road accidents) (Figure 6$)$.

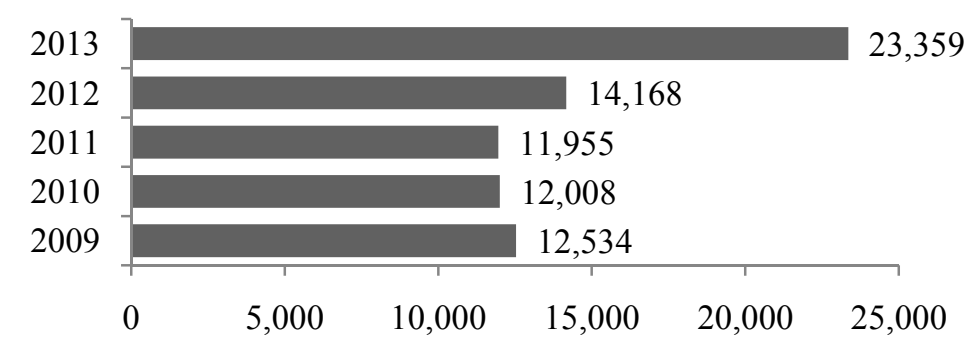

Figure 6. Road accident statistics in Kazakhstan

Note. Made by the author based on Official website of the Ministry of National Economy of the Republic of Kazakhstan. Department of Statistics (2015).

The overall state of the market of compulsory retail insurance in Kazakhstan can be described as stable, which is confirmed by the positive kinetics of its basic development indicators (Figure 7).

Nevertheless, despite the fact that the number of net insurance premiums exceeds the number of insurance benefits in the period under review, there was a moderately falling tendency in the economic effect. There was a $32 \%$ decrease in the economic effect of compulsory retail insurance 2009 to 2014 . This was due to an almost $20 \%$ decrease in insurance premiums in Kazakhstan from 2012 to 2014 as well as a significant increase in the share of insurance benefits in total net insurance premiums (Figure 8). 


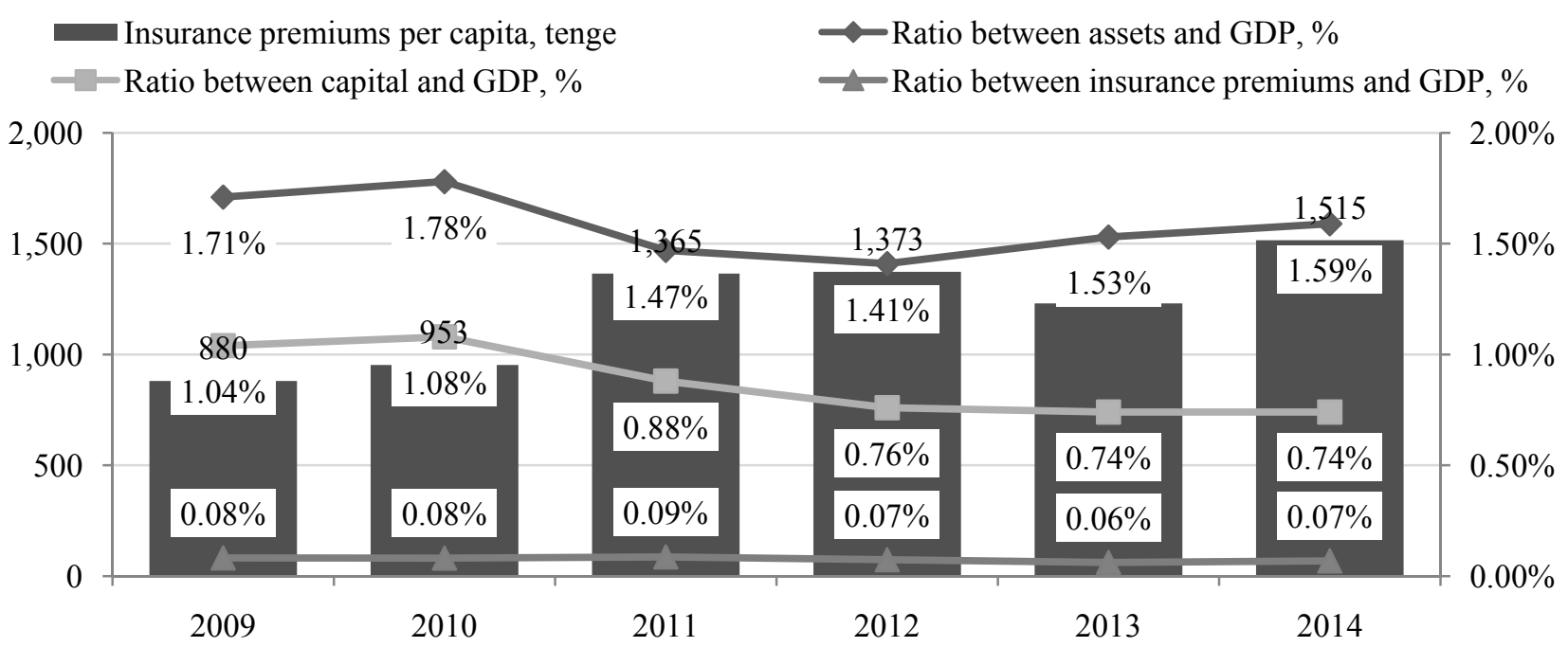

Figure 7. Macroeconomic development indicators of compulsory retail insurance in Kazakhstan

Note. Made by the author based on the information from Official website of the National Bank of the Republic of Kazakhstan (2015), Official website of the Ministry of National Economy of the Republic of Kazakhstan, Department of Statistics (2015).

Civil and legal liability of vehicle owners profits

- Share of insurance benefits in net civil and legal liability of vehicle owners premiums

$\longrightarrow$ Economic effect, $\%$

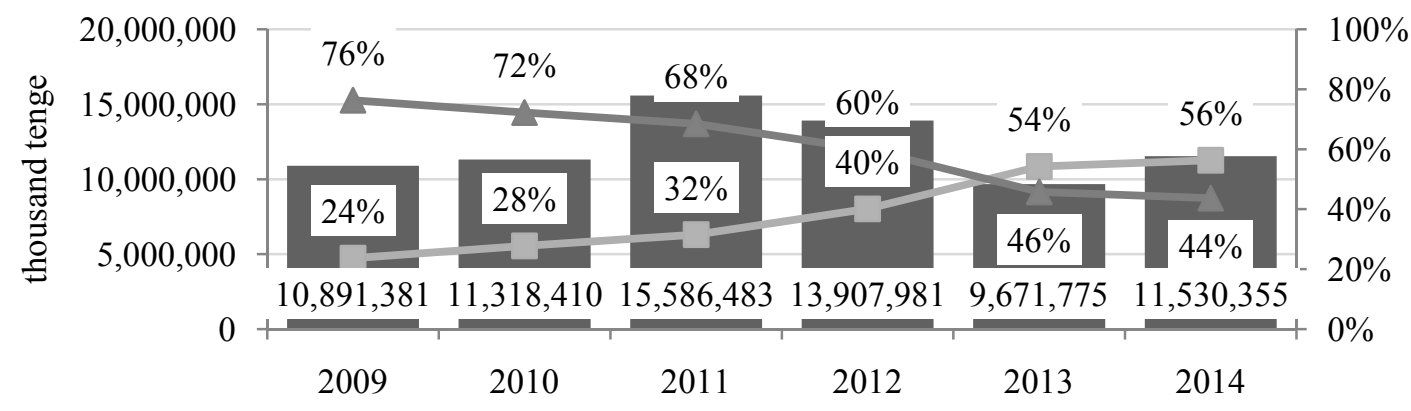

Figure 8. Economic effect indicators of compulsory retail insurance in Kazakhstan

Note. Made by the author based on the information from Official website of the National Bank of the Republic of Kazakhstan (2015).

Taking into consideration the decrease in insurance premiums, there was some dumping on the market with regard to both pricing and services of intermediate parties, which in the end may result in companies being unable to fulfil their obligations due to insufficient insurance funds.

Today the system compulsory retail insurance of Kazakhstan is poorly developed as compared with the western retail market, where each person has 5 to 6 contracts of compulsory retail insurance (Eurasian Insurance Risks, 2014). The number of individuals who have insured their property, car, life, or health is rather small in Kazakhstan. The following peculiarity is inherent in the Kazakhstan insurance market: growth in retail insurance premiums is caused by the growth in lending, because to get a loan to buy a car or apartment, it is necessary to get an insurance policy from one of the captive insurance companies of the same bank. Reduced lending resulted in reduced bank insurance. Kazakhs are not willing to voluntary insure their property and liability not because of the crisis, but because they are not fully aware of the principles of insurance as a tool of financial protection from undesired events (Saimbetova \& Isakova, 2011). 
Meanwhile, the competitive struggle on the insurance market forces the companies to improve their service as well as ensure that the people receive good information and consultations. Today more and more people come to realize that in crisis conditions retail insurance becomes crucial for their functioning, because in case of, for instance, property loss it would be difficult to restore it, provided getting a loan is not possible (Hasenova, 2010).

Another peculiarity of the market of compulsory retail insurance is its high structural concentration. Firstly, the retail insurance market of Kazakhstan is characterized by high regional concentration. Thus, the city of Almaty alone is accounted for $38 \%$ of total insurance benefits and $34 \%$ of total insurance premiums in the Republic of Kazakhstan (Figure 9).

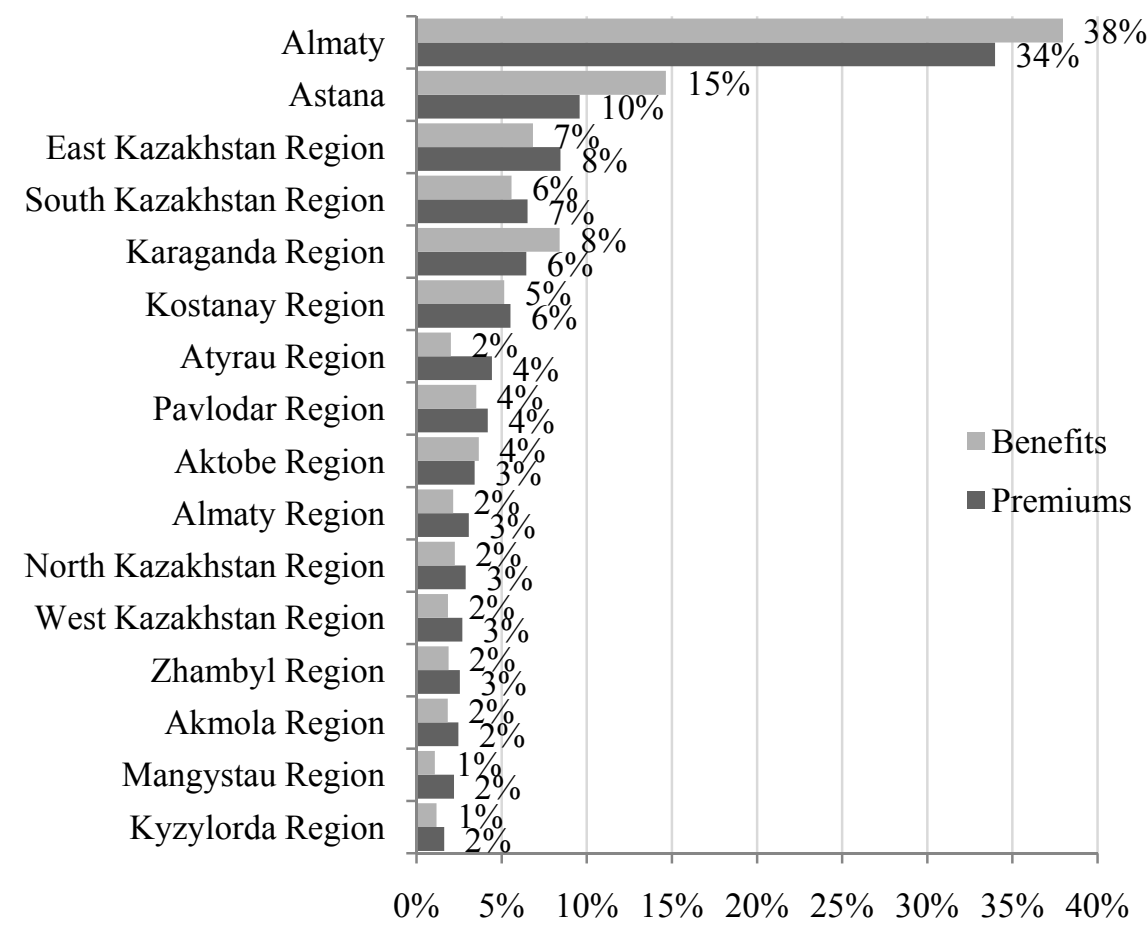

Figure 9. Regional concentration of compulsory retail insurance premiums and benefits in Kazakhstan 01.01.2015

Note. Made by the author based on the information from Official website of the National Bank of the Republic of Kazakhstan (2015).

The rest of the regions of the country are characterized by low penetration levels of insurance services, which indicates territorial unevenness of the market of compulsory retail insurance, caused by, above all, the difference in purchasing power of the people living in Kazakhstan and awareness regarding various types of insurance services.

Kazakhstan's market of compulsory retail insurance is also characterized by functional concentration. The analysis indicates that just one company, "SK "NOMAD Insurance" AO, accounts for about $20 \%$ of insurance transactions with regard to insurance of civil and legal liability of vehicle owners. At the same time, the country's three leading insurance companies account for $44 \%$ of insurance transactions, which significantly reduces the competitive capacity of the insurance market, thus causing reduction in the quality of insurance services (Figure 10). 


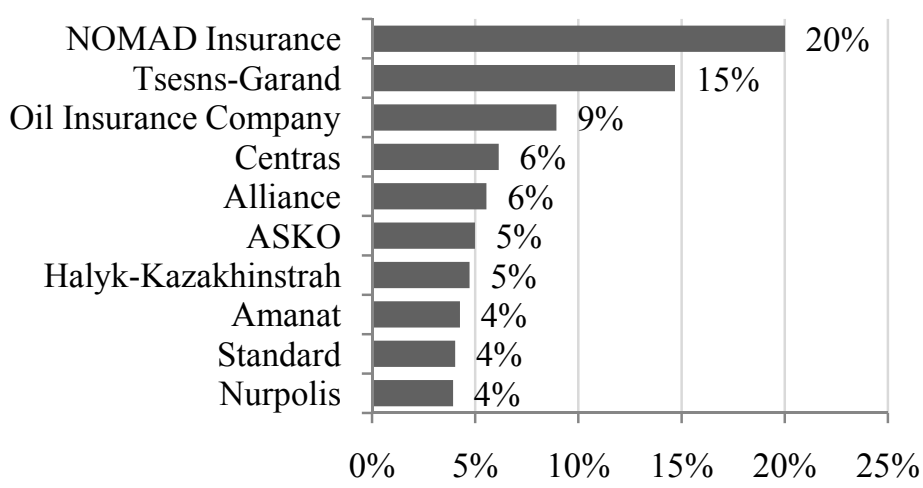

Figure 10. Functional concentration of the market of compulsory retail insurance in Kazakhstan 01.01.2015

Note. Made by the author based on the information from Official website of the National Bank of the Republic of Kazakhstan (2015).

External and internal environment factors have a major impact on the functioning and development of the market of compulsory retail insurance.

While analysing what impacts the development of the insurance market, they encounter a problem of excessive information, when the variables (impact factors) are multicollinear. To ensure the adequacy of the evaluation of the real process, it is reasonable to replace the multiple impact factors with a less number of uncorrelated values that would preserve all of the information on the cause-effect mechanism of influencing the development of the retail insurance market, without affecting the accuracy of the analysis results (Bureeva, 2014).

As a tool for such modification, a principle component analysis (factor analysis) was performed in the research. The factor analysis is one of those methods, which were designed for the purposes of one specific science but later acquired a more extensive interdisciplinary signification. Nowadays the factor analysis has the status of a general scientific method and multiparametric object visualization tool for economic analysis. The method was designed to reveal key indicators of the impact on the characteristics by reducing the data to form principle components to interpret the generalized character of this impact (Bureeva, 2014).

To perform an exploratory analysis of the impact factors have on the development of the market of compulsory retail insurance in Kazakhstan, a system of empirical data was formed consisting of 19 indicators characterizing the social and economic state of Kazakhstan and world economy's financial and real sectors. The empirical sample was formed based on the data from the second quarter of 2004 to the fourth quarter of 2013. It consists of 39 values for each of the variables. The STATISTICA 7.0 suite was used to perform the principle component analysis.

To determine the optimum number of internal and external environment factors impacting the development of the market of compulsory retail insurance of Kazakhstan, factors which eigenvalue is not less than 1 (Kettle criterion) were considered (factors which eigenvalue is less than the critical value have no significant impact on the correlation matrix) (Table 1).

Table 1. Statistical characteristics of the calculated principle components

\begin{tabular}{lllll}
\hline Value & \multicolumn{4}{c}{ Eigenvalues (факторы (B2:AN40)) } \\
& $\begin{array}{l}\text { Extraction: Principal components } \\
\text { Eigenvalue }\end{array}$ & \% Total variance & Cumulative Eigenvalue & Cumulative \% \\
\hline 1 & 6.556038 & 34.50546 & 6.55604 & 34.50546 \\
2 & 3.457262 & 18.19612 & 10.01330 & 52.70158 \\
3 & 1.850350 & 9.73869 & 11.86365 & 62.44027 \\
4 & 1.763677 & 9.28251 & 13.62733 & 71.72278 \\
\hline
\end{tabular}


The visual evaluation of the tendency in impact factors' eigenvalue is shown in Figure 11, where with the help of the scree plot it can be stated that in point 4 the drop inhibition is the greatest.

The cumulative dispersion of the four factors of social and economic state of Kazakhstan and development trends of the world economy's financial and real sectors indicates that they determine $71.7 \%$ of the development tendency of the market of compulsory retail insurance. This indicates an adequate factor solution.

\section{Eigenvalue curve}

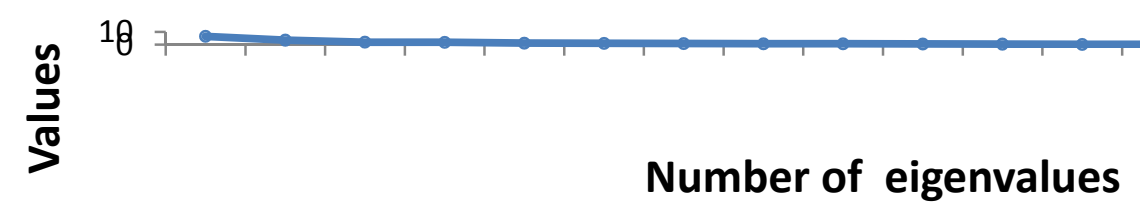

Figure 11. Determining the optimal number of factors based on the screen plot

To determine the optimal factor structure, the factors were rotated according to the Equamax procedure (table 2). Four factor groups were formed (standardized values) which have a major impact on the development tendency of the market of compulsory retail insurance in Kazakhstan (factor loadings taken into consideration are those exceeding 0.7) (table 3).

Thus, based on the analysis conducted, it can be stated that today the market of compulsory retail insurance in Kazakhstan is determined by:

$34.5 \%$ - development trends of the economies and financial markets of developed countries;

$18.2 \%$ - state of the internal investment climate, balanced budget and personal crediting levels;

$9.7 \%$ - state of the country's engineering industry and cost of loan capital;

$9.2 \%$ - customer demand and foreign investments.

\section{Discussion}

Based on the results, it can be concluded that as of today the market of compulsory retail investment in Kazakhstan depends largely on the development trends of the world economy and personal crediting efficiency within the state.

Based on the calculated factor loadings on the development of the market of compulsory retail insurance in Kazakhstan with the use of the correlation-regression analysis, a model forecasting the market efficiency (cost-efficiency) for 2015 was developed, key impact factors taken into consideration (formula 1).

Table 2. Matrix of factor loadings of the social and economic state of Kazakhstan and development trends of the world economy's financial and real sectors on the market of compulsory retail insurance in Kazakhstan

\begin{tabular}{lrrrr}
\hline Variable & \multicolumn{4}{l}{$\begin{array}{l}\text { Factor Loadings (Equamax raw) } \\
\text { Extraction: Principal components }\end{array}$} \\
& $\begin{array}{l}\text { Marked loadings are }>.700000 \text { ) } \\
\text { (Mactor }\end{array}$ & Factor 4 \\
\cline { 2 - 5 } & Factor 1 & Factor 2 & Factor 3 & F \\
\hline Real income, in \% compared with the previous year & 0.573565 & 0.683334 & 0.031009 & -0.325234 \\
GDP in \% compared with the previous year & 0.202190 & 0.720276 & -0.511466 & -0.240578 \\
Investment in capital in\% compared with the previous year & 0.122213 & 0.899923 & 0.180173 & 0.091938 \\
Consumer price index & 0.259273 & 0.262859 & 0.133495 & -0.791591 \\
Yearly average exchange rate of the US dollar & -0.118371 & -0.311788 & -0.625715 & 0.082175 \\
Budget deficit (surplus) growth rates & -0.106179 & -0.747189 & 0.036002 & 0.352360 \\
\hline
\end{tabular}




\begin{tabular}{lrrrr}
\hline Unemployment growth rates, \% & 0.342625 & -0.611038 & 0.173810 & -0.395390 \\
Growth rates of manufacture of vehicle, (semi)trailers & 0.151044 & -0.170467 & 0.870444 & 0.080621 \\
Gross inflow rates of foreign direct investment & -0.087494 & -0.103218 & 0.105086 & 0.746639 \\
Personal lending growth rates & -0.084295 & 0.923918 & -0.181996 & 0.037580 \\
Growth of rates of return for personal deposits & -0.414072 & 0.368179 & -0.294781 & -0.321685 \\
Growth of interest rates for personal loans in the national & -0.154192 & -0.369635 & 0.760384 & -0.261352 \\
currency & & & & \\
Dow Jones Industrial Average growth rates & -0.899300 & 0.023589 & -0.221037 & 0.038930 \\
DAX growth rates & -0.747967 & 0.181613 & 0.179508 & 0.275566 \\
GDP growth rates in Germany & 0.803837 & 0.439315 & -0.145081 & 0.034522 \\
GDP growth rates in France & 0.759940 & 0.564621 & 0.045421 & 0.003374 \\
GDP growth rates in China & 0.285156 & 0.088523 & 0.243548 & -0.471602 \\
GDP growth rates in Russia & 0.574901 & 0.626356 & -0.075837 & -0.243457 \\
GDP growth rates in USA & 0.204567 & 0.423958 & -0.012293 & 0.118383 \\
Expl. Var & 3.873032 & 5.184614 & 2.372197 & 2.197486 \\
Prp. Totl & 0.203844 & 0.272874 & 0.124852 & 0.115657 \\
\hline
\end{tabular}

Note. Calculated by the author based on the information from Official website of the National Bank of the Republic of Kazakhstan (2015), Official website of the Ministry of the National Economy of the Republic of Kazakhstan. Department of Statistics (2015), Official website of Bloomberg (2015), Official website of the World Bank (2015).

Table 3. Factor loading of the social and economic state of Kazakhstan and development trends of the world economy's financial and real sectors on the market of compulsory retail insurance in Kazakhstan

\begin{tabular}{|c|c|c|c|}
\hline Factor 1 & Factor 2 & Factor 3 & Factor 4 \\
\hline $\begin{array}{l}\text { Dow Jones Industrial } \\
\text { Average growth rates }\end{array}$ & $\begin{array}{l}\text { GDP in \% compared with } \\
\text { the previous year }\end{array}$ & $\begin{array}{l}\text { Growth rates of } \\
\text { manufacture of vehicles, } \\
\text { trailers and semitrailers }\end{array}$ & Consumer price index \\
\hline DAX growth rates & $\begin{array}{l}\text { Investments in fixed } \\
\text { capital in \% compared } \\
\text { with the previous year }\end{array}$ & $\begin{array}{l}\text { Growth of interest rates } \\
\text { for personal loans in the } \\
\text { national currency, } \%\end{array}$ & $\begin{array}{l}\text { Gross inflow rates of } \\
\text { foreign direct investment }\end{array}$ \\
\hline $\begin{array}{l}\text { GDP growth rates in } \\
\text { Germany }\end{array}$ & $\begin{array}{l}\text { Budget deficit (surplus) } \\
\text { growth rates }\end{array}$ & & \\
\hline $\begin{array}{l}\text { GDP growth rates in } \\
\text { France }\end{array}$ & $\begin{array}{l}\text { Personal lending growth } \\
\text { rates }\end{array}$ & & \\
\hline 34.5 & 18.2 & 9.7 & 9.3 \\
\hline \multicolumn{4}{|c|}{ Cumulative factor loading $71.7 \%$} \\
\hline
\end{tabular}

$$
1.537+0.401 * X_{1}+0.612 * X_{2}+0.427 * X_{3}-0.296 * X_{4}
$$

where,

$\mathrm{X}_{1}$ - forecasted quarterly Dow Jones Industrial Average growth rates;

$\mathrm{X}_{2}$ - forecasted quarterly personal lending growth rates;

$\mathrm{X}_{3}$ - forecasted quarterly growth rates of manufacture of vehicles, trailers and semitrailers;

$\mathrm{X}_{4}$ - forecasted quarterly consumer price index.

The main characteristics of the adequacy of the correlation-regression model of the efficiency of the Kazakhstan 
compulsory retail insurance market are provided in table 4 .

Table 4. Statistical characteristics of the adequacy of the correlation-regression model of the efficiency of the Kazakhstan compulsory retail insurance market

\begin{tabular}{|c|c|c|c|c|c|c|}
\hline \multirow[t]{2}{*}{$\mathrm{N}=24$} & \multicolumn{6}{|c|}{$\begin{array}{l}\text { Regression Summary for Dependent Variable: Y (Внутренние факторы) } \\
\mathrm{R}=.94851950 \mathrm{R} ?=.899689 \text { Adjusted R?= } .85368914 \\
\mathrm{~F}(4,19)=12.0442 \mathrm{p}<.00073 \text { Std.Error of estimate: } .00421\end{array}$} \\
\hline & Beta & $\begin{array}{l}\text { Std.Err. } \\
\text { Beta }\end{array}$ & of $\mathrm{B}$ & Std.Err. of B & $\mathrm{t}(19)$ & p-level \\
\hline Intercept & & & 1.537 & 0.0089 & 4.52212 & 0.000574 \\
\hline $\mathrm{X}_{1}$ & 0.756978 & 0.296098 & 0.401 & 0.0084 & 4.84086 & 0.000322 \\
\hline $\mathrm{X}_{2}$ & 0.643918 & 0.267052 & 0.612 & 0.0005 & 2.53508 & 0.002489 \\
\hline $\mathrm{X}_{3}$ & 0.564521 & 0.358215 & 0.427 & 0.0073 & 2.20353 & 0.003620 \\
\hline $\mathrm{X}_{4}$ & -0.275177 & 0.232130 & -0.296 & 0.0096 & -2.04261 & 0.004153 \\
\hline
\end{tabular}

Note. Calculated by the author based on the information from Official website of the National Bank of the Republic of Kazakhstan (2015), Official website of the Ministry of the National Economy of the Republic of Kazakhstan. Department of Statisticb (2015), Official website of Bloomberg (2015), Official website of the World Bank (2015).

Forecasted factor loading values based on the extrapolation method with the use of the trend line are shown in Figure 12, 13, 14, 15, and Table 5.

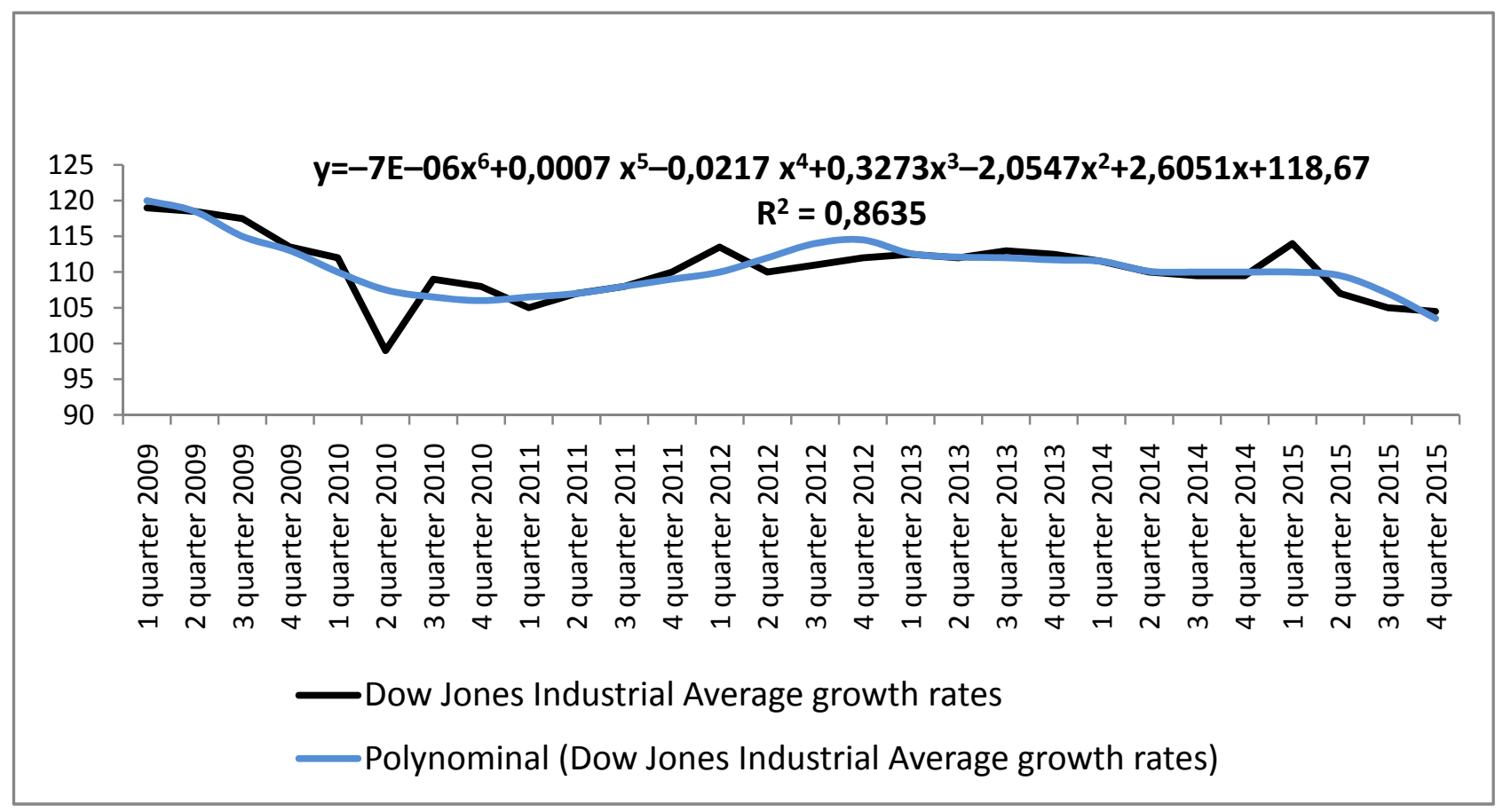

Figure 12. Tendency in the actual and forecasted DJIA growth rates

Note. Calculated by the author based on the information from Official website of Bloomberg (2015), Official website of the World Bank (2015). 


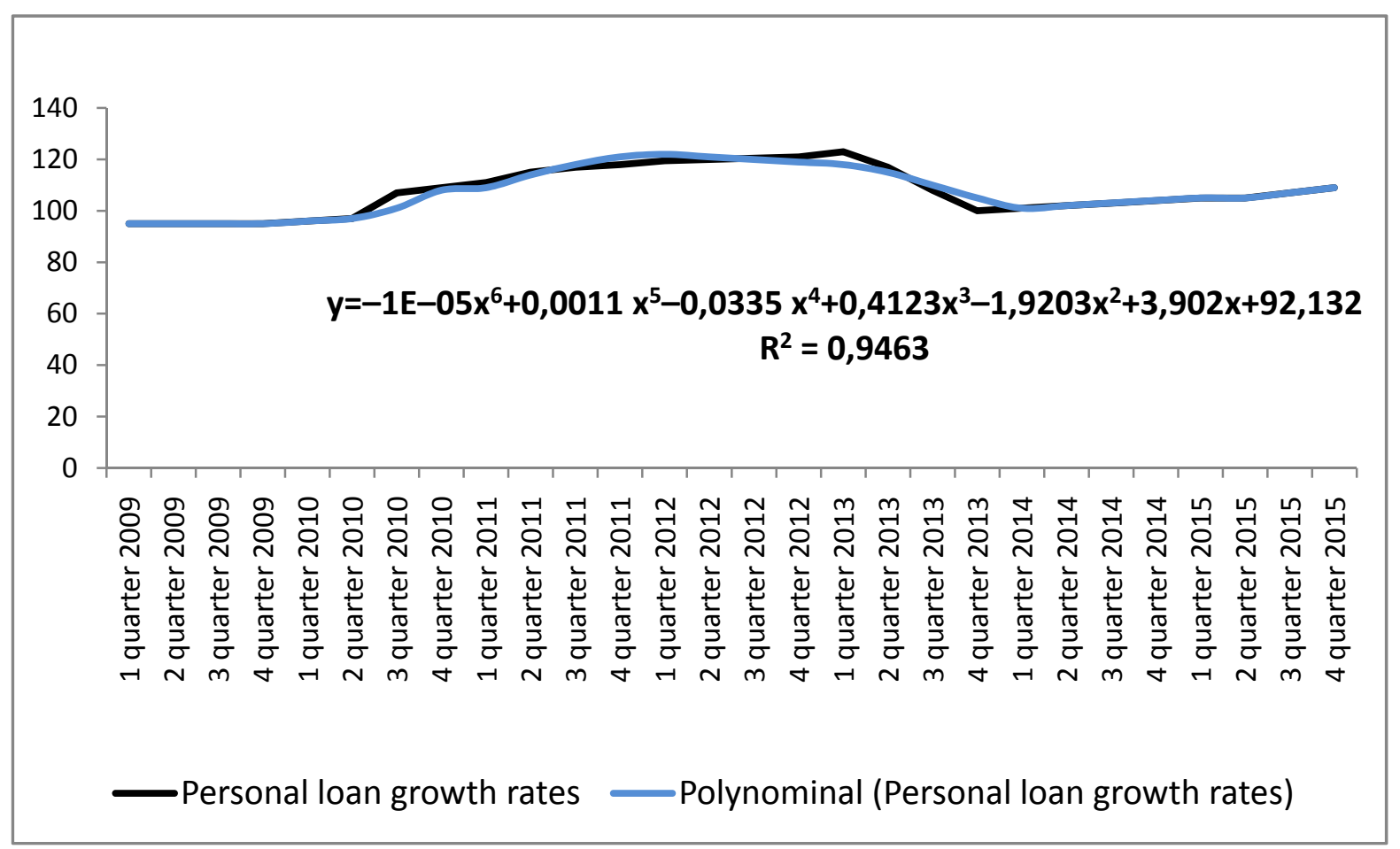

Figure 13. Tendency in values and forecasted personal lending growth rates in Kazakhstan

Note. Calculated by the author based on the information from Official website of the National Bank of the Republic of Kazakhstan (2015), Official website of the Ministry of National Economy of the Republic of Kazakhstan. Department of Statistics (2015).

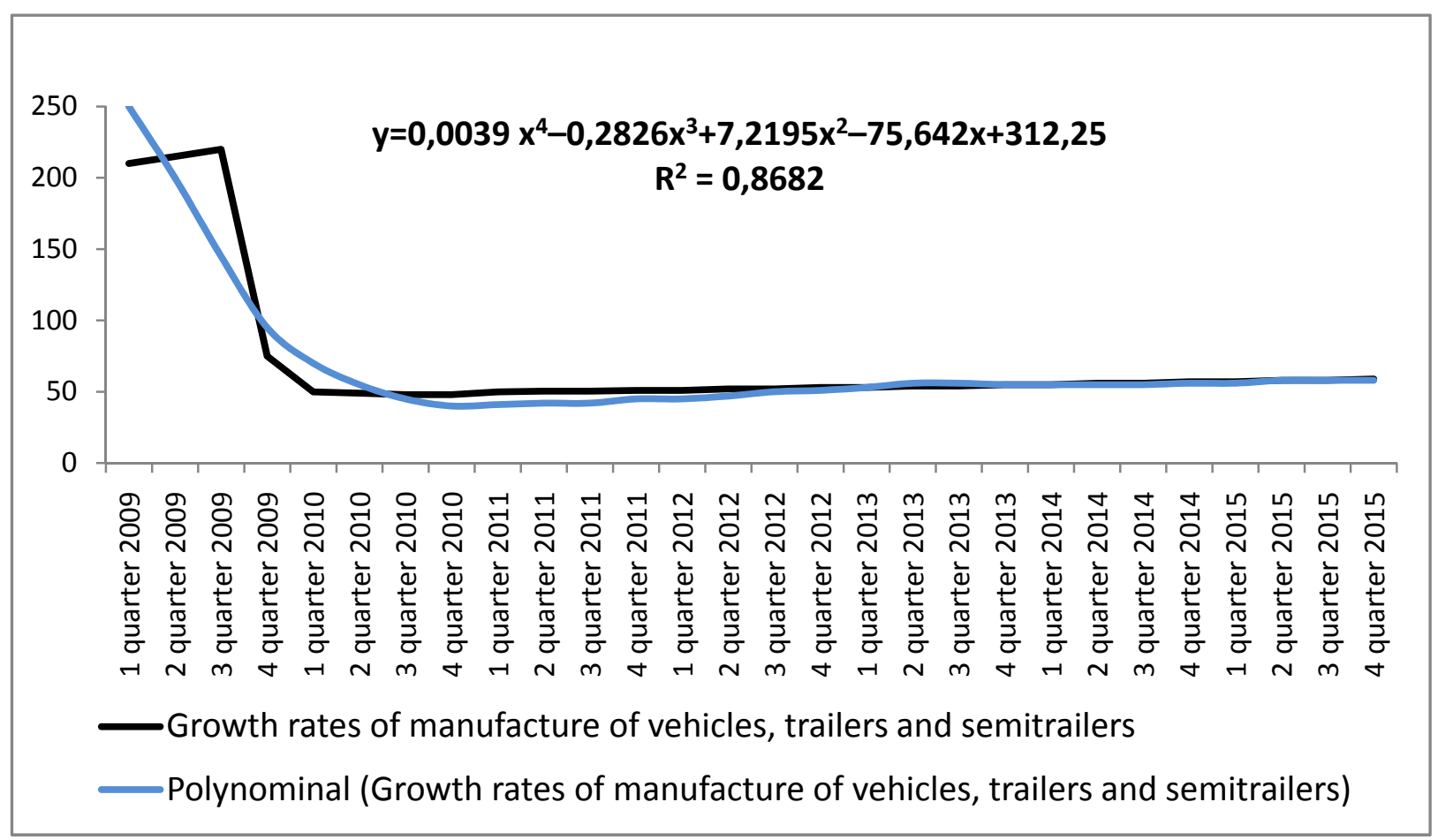

Figure 14. Tendency in and forecasted growth rates of manufacture of vehicles, trailers, and semitrailers Note. Calculated by the author based on the information from Official website of the National Bank of the Republic of Kazakhstan (2015), Official website of the Ministry of National Economy of the Republic of Kazakhstan. Department of Statistics (2015). 


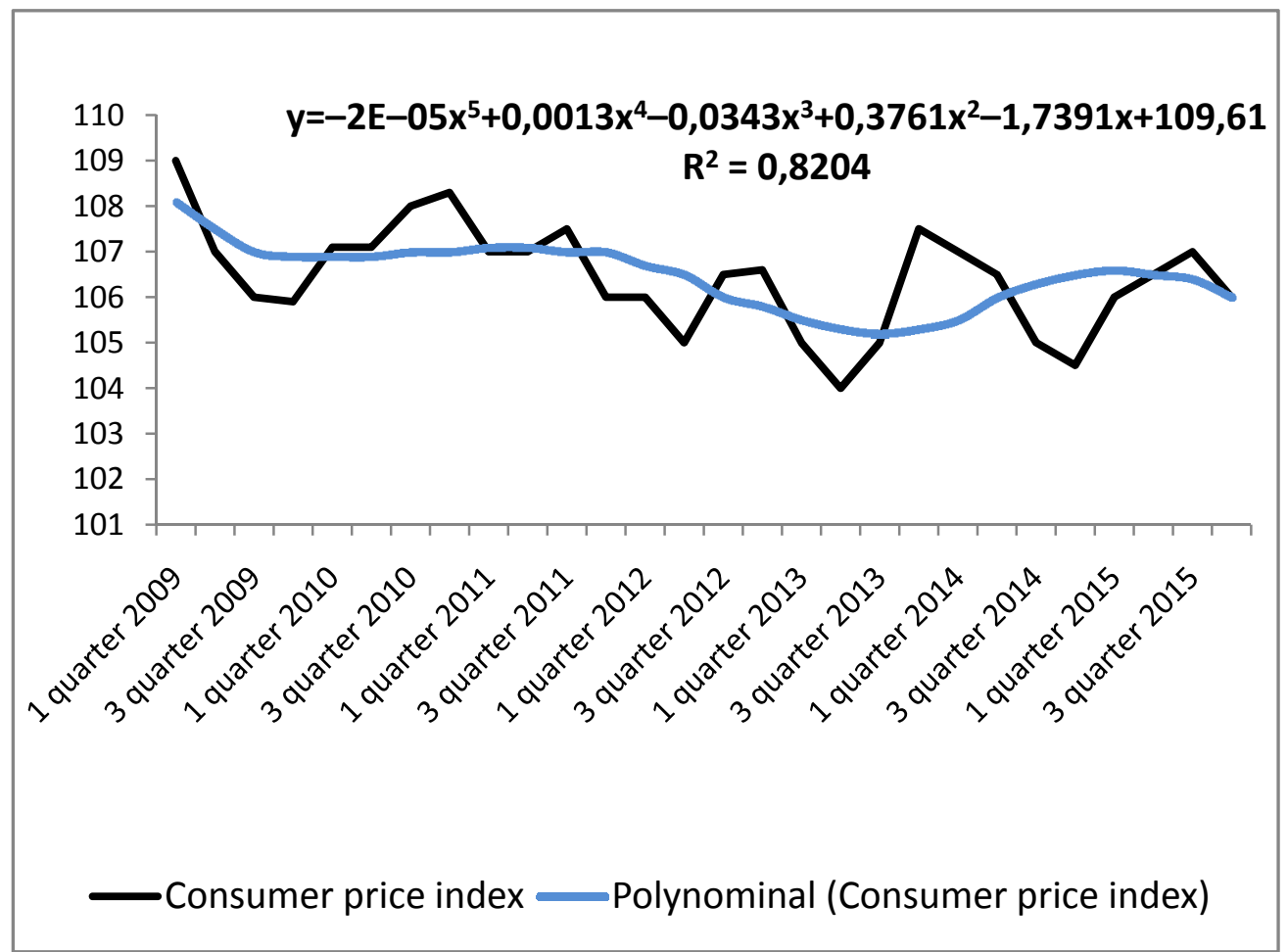

Figure 15. Consumer price index tendency in Kazakhstan

Note. Calculated by the author based on the information from Official website of the National Bank of the Republic of Kazakhstan (2015), Official website of the Ministry of National Economy of the Republic of Kazakhstan. Department of Statistics (2015).

Table 5. Forecasted values of the basic factor loadings of the market of compulsory retail insurance in Kazakhstan and its efficiency (cost-efficiency)

\begin{tabular}{llllll}
\hline & $\begin{array}{l}\text { Earnings growth } \\
\text { rates }\end{array}$ & $\begin{array}{l}\text { DJIA growth } \\
\text { rates }\end{array}$ & $\begin{array}{l}\text { Personal lending } \\
\text { growth rates }\end{array}$ & $\begin{array}{l}\text { Growth rates of } \\
\text { manufacture } \\
\text { vehicles, trailers and } \\
\text { semitrailers }\end{array}$ & $\begin{array}{l}\text { Consumer } \\
\text { index }\end{array}$ \\
\hline 1 quarter 2015 & 109.666 & 113.4181 & 115.958 & 54 & 106 \\
2 quarter 2015 & 108.3675 & 108.4043 & 116.7624 & 55 & 106.7 \\
3 quarter 2015 & 111.3651 & 106.3905 & 122.5669 & 55,8 & 107 \\
4 quarter 2015 & 111.7435 & 105.3767 & 123.3713 & 56 & 106.3 \\
\hline
\end{tabular}

Therefore, based on the identified peculiarities of the current market of compulsory retail insurance in the Republic of Kazakhstan, and taking into consideration the specific factor loadings of the country's social and economic state and development trends of the world economy's financial and real sectors on its development, a positive prospective tendency for building the retail insurance financial potential in Kazakhstan in 2015 was revealed. Thus, the forecasted compulsory retail insurance market efficiency will grow from $109.7 \%$ in early 2015 to $111.7 \%$ in late 2015 . The following efficiency-enhancing measures, in our opinion, could be the foundation for the build-up and ideological concept of Kazakhstan's retail insurance reproduction:

1) Implementation of economic measures by the state to force individuals to buy insurance by means of developing special legislative acts;

2) State motivation to increase the competitive capacity of the industry; clear it from schemes and dishonest players, establishment of a civilized and transparent market as such;

3) Improvement of retail insurance services and opening direct sales offices; 
4) Professional development of insurance agents;

5) Design and implementation of various innovative types of compulsory retail insurance, etc.

6) Implementation of the above measures may become the foundation for building the financial potential of the market of compulsory retail insurance in Kazakhstan, raising awareness of the people, and increasing the cumulative economic efficiency of the country's retail insurance.

\section{Conclusion}

The conducted analysis was revealed that the current state of the market of compulsory retail insurance of the Republic of Kazakhstan is characterized by stable development along with falling economic efficiency during the reviewed period from 2009 to 2014. These were accompanied by the tendencies of reducing insurance premiums when insuring civil and legal liability of vehicle owners. The main peculiarities of the functioning of the market of compulsory retail insurance in Kazakhstan were defined. These include regional and functional market concentration, which leads to its reduced competitive power and quality of insurance services. Using a principle component analysis, it was identified that the development tendencies of the market of compulsory retail insurance in Kazakhstan are determined by, above all, the world economy's development trends and personal crediting levels in the state. A complex of measures to enhance the efficiency of the market of compulsory retail insurance in Kazakhstan was outlined to maintain and consolidate the forecasted positive tendency of the market efficiency growth for 2015, and form the sources for building its financial potential. Mechanisms for building the financial potential and methods to enhance the efficiency of the market of compulsory retail insurance in the Republic of Kazakhstan may become the foundation for further scientific research on this subject.

\section{References}

Bureeva N. N. (2014). Multivariate statistical analysis with the use of application package "STATISTICA" (p. 114). Nizhny Novgorod.

Eurasian Insurance Risks. (2014). Ekonomicheskaya gazeta, 62(1774). Retrieved from http://www.neg.by/publication/2014_08_22.html

Global insurance review 2014 and outlook 2015 and 2016. (2015). Economic Research \& Consulting. Retrieved from http://www.pii.ir/resource-latin/Global-insurance.pdf

Hasenova, K. E. (2010). Improvement of the financial-organizational mechanism of personal insurance in the Republic of Kazakhstan. Author's abstract of dissertation for Ph.D. in Economics (p. 25). Almaty.

Ing, \& Elena, S. (2014). Selected Areas of Insurance Industry and Competitiveness of Commercial Insurance Companies. In Financial Assets and Investing (1/2014, pp. 62-70).

Kindurys, V. (2011). Life assurance business and its development tendencies and manifestations in Lithuania: theoretical and practical aspects. In Monograph. Vilnius: Vilnius University (p. 574).

Milyaeva M. B., \& Ninua S. A. (2014). The state of the market of insurance services in the Republic of Kazakhstan and prospects of Russian insurers entering it . In Rossiysky vneshnekonomichesky vestnik (pp. 49-59).

Official website of Bloomberg. (2015). http://www.bloomberg.com/

Official website of the Ministry of National Economy of the Republic of Kazakhstan, Department of Statistics. (2015). http://www.stat.gov.kz/

Official website of the National Bank of the Republic of Kazakhstan. (2015). http://www.nationalbank.kz/?docid=275\&switch=russian

Official website of the World Bank. (2015). http://www.worldbank.org/

On Approved Compulsory Insurance Types (Order of the Prime Minister of the Republic of Kazakhstan No.38-p). (2003). Retrieved from http://kazakhstan.news-city.info/docs/sistemsx/dok_ieqlgo.html

On Insurance Activity (Law of the Republic of Kazakhstan No.126-II). (2000). Retrieved from http://online.zakon.kz/Document/?doc_id=1021136

On Compulsory Insurance of Civil and Legal Liability of Vehicle Owners (Law of the Republic of Kazakhstan No. 446-II). (2003). Retrieved from http://online.zakon.kz/document/?doc_id=1041172

On Compulsory Social Insurance (Law of the Republic of Kazakhstan No. 405-II). (2003). Retrieved from http://online.zakon.kz/Document/?doc_id=1039354 
Ramazanov, N. (2015). Running in place. Financiers association of Kazakhstan. Delovaya Nedelya, 6(1130). Retrieved from http://afk.kz/index.php/ru/ strahovoi-sektor/12811-2015-02-23-08-50-26

Richard, C., Lawson, M., \& Todd T. (2013). Fair Valuation of Insurance Liabilities: Principles and Methods. In Public Policy Monograph (p. 50). USA: American Academy of Actuaries.

Saimbetova, B. T., \& Isakova D. I. (2011). Compulsory insurance in Kazakhstan: State and development tendencies (p. 109). Taraz: Taraz State University named after M. Kh. Dulaty.

Yahoo. (2015). https://www.yahoo.com/

Zhilkina, A. N. (2014). Innovative approach to insurance business management. Monograph. Saint Petersburg (p. 126). The Saint Petersburg University of Management and Economics.

Zhuyrikov, K. K. (2013). The insurance market of Kazakhstan-what have we come to? Delovaya Nedelya, 31(1056). Retrieved from http://dn.kz/?option=com content\&view=article\&id=1371:2013-08-23-06-04-08\&catid=5:2011-10-23-11-45-05\&Itemid=16

Zhuyrikov, K. K. (2014). Insurance in Kazakhstan-Further paths of development (p. 278). Zhibek Zholy.

\section{Copyrights}

Copyright for this article is retained by the author(s), with first publication rights granted to the journal.

This is an open-access article distributed under the terms and conditions of the Creative Commons Attribution license (http://creativecommons.org/licenses/by/3.0/). 